\title{
Regulation of FADS2 expression and activity in European sea bass (Dicentrarchus labrax, L.) fed a vegetable diet
}

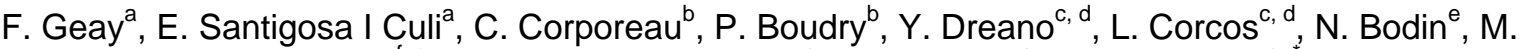 \\ Vandeputte $^{f, g}$, J.L. Zambonino-Infante ${ }^{\mathrm{a}}$, D. Mazurais ${ }^{\mathrm{a}}$ and C.L. Cahu ${ }^{\mathrm{a},{ }^{*}}$
}

\footnotetext{
a Ifremer Marine Fish Nutrition Team, Nutrition Aquaculture and Genomics Research Unit, UMR 1067, Ifremer, Technopole Brest-Iroise, BP 70, 29280 Plouzané, France

${ }^{\mathrm{b}}$ UMR 100 PE2M Ifremer-Université de Caen, Ifremer Centre de Brest, B.P. 70, Plouzané, France

c Université de Brest, INSERM, U613, ECLA, Brest F-29200, France

d Université Européenne de Bretagne, Faculté de médecine, Brest F-29200, France

${ }^{e} \mathrm{CRH}$, UMR 212 EME, Institut de Recherche et de Développement, Av Jean Monnet BP171, 34203 Sète, France

${ }^{f}$ Ifremer, chemin de Maguelone, F-34250 Palavas les Flots, France

g INRA, UMR 1313 Génétique Animale et Biologie Intégrative, Domaine de Vilvert, 78350 Jouy-en-Josas, France

*: Corresponding author : C.L. Cahu, Tel.: +33 2982244 03; fax: +33 2982243 66, email address :

Chantal.Cahu@ifremer.fr
}

\begin{abstract}
:
Supplies of marine fish oils are limited, and continued growth in aquaculture production dictates that lipid substitutes in fish diets must be used without compromising fish health and product quality. In this study, the total substitution of a fish meal and fish oil by a blend of vegetable meals (corn, soybean, wheat and lupin) and linseed oil in the diet of European sea bass (Dicentrachus labrax) was investigated. Two groups of European sea bass were fed with fish diet (FD) or vegetable diet (VD) for 9 months. VD, totally deprived of eicosapentaenoate (EPA; 20:5n-3) and docosahexaenoate (DHA; 22:6n-3), revealed a nutritional deficiency and affected growth performance. Whilst VD induced a significant increase in fatty acid desaturase 2 (FADS2) and sterol binding regulatory element-binding protein 1 (SREBP-1) mRNA levels, the desaturation rate of $\left[1-{ }^{14} C\right] 18: 3 n-3$ into $\left[1-{ }^{14} C\right] 18: 4 n-3$, analysed in microsomal preparations using HPLC method, did not show an upregulation of FADS2 activities in liver and intestine of fish fed VD. Moreover Western-blot analysis did not revealed any significant difference of FADS2 protein amount between the two dietary groups.
\end{abstract}

These data demonstrate that sea bass exhibits a desaturase (FADS2) activity whatever their diet, but a post-transcriptional regulation of fads2 RNA prevents an increase of enzyme in fish fed a HUFA-free diet. This led to a lower fish growth and poor muscle HUFA content.

Keywords: Sea bass (Dicentrarchus labrax); FADS2 expression and activity; HUFA biosynthesis 


\section{Introduction}

It is well known that $n-3$ highly unsaturated fatty acids (HUFA) eicosapentaenoate (EPA; 20:5n-3) and docosahexaenoate (DHA; 22:6n-3) induce many health benefits for fish as well as for their consumers including human (Burr, 1981; Simopoulos, 2000). Until now, high n-3 HUFA levels in flesh of farmed fish have been obtained by fish oil incorporation in diet formulation. However, such feeding based on availability of natural fish resources is not sustainable, and will constrain continuing growth of aquaculture activities (Pike, 2005). In this context, fish oil replacement by vegetable oils, rich in $\mathrm{C}_{18}$ short chain fatty acids (PUFA) but devoid of the n-3 HUFA, may help to reduce the aquaculture industry's dependence on wild fisheries. This is the case for the European sea bass (Dicentrarchus labrax) culture which is among the most important concerning carnivorous marine finfish species in Europe. Freshwater fish species fed a diet rich in C18 PUFA are able to maintain a certain degree mourof desaturase and elongase activities to produce HUFA, including EPA and DHA (Tocher et al., 2001; Tocher et al., 2004). On the contrary, marine fish species including sea bass are unable to produce HUFA from either linolenic acid ( 18:3n-3: LNA) or linoeic acid $(18: 2 n-6:$ LA) at a physiologically significant level due to apparent deficiencies in one or more steps of the metabolic pathway (Owen et al., 1975; Ghioni et al., 1999; Tocher and Ghioni, 1999). In order to determine the reasons for this deficiency in marine species, special attention has been paid to characterise the delta 6 desaturase gene fads 2 product, the FADS2, which has been shown in mammals to catalyze the first limiting step in the HUFA biosynthesis pathway (Sprecher et al., 1995 ; Cho et al., 1999a b; Marquardt et al., 2000 ; Innis 2003; Nakamura et Nara, 2004). cDNAs for FADS2 have been cloned from marine species, including European sea bass (Gonzáles-Rovira et al., 2009; Santigosa et al., 2010). The functional characterization of the corresponding proteins by heterologous yeast expression system showed that enzymes are able to transform LNA and LA into 18:4n-3 and 18:3n-6, respectively (sea bream: Seiliez et al., 2003; cod: Tocher et al., 2006; sea bass: Gonzáles-Rovira et al., 2009; Santigosa et al., 2010). These data support the hypothesis that the poor ability of marine fish species, and particularly sea bass, to bioconvert PUFA into HUFA is not due to lack of FADS2.

However, whilst it was reported a stimulation of FADS2 activity, which is correlated to an up regulation of gene expression, in freshwater fish species fed vegetable diets (Zheng et al., 2005a), such nutritional regulation is more controversed in marine fish species. In cod, both FADS2 expression and activity were not significantly increased in liver and intestine of fish fed $100 \%$ vegetable oil (Tocher et al., 2006) whilst the expression was up regulated by a similar nutritional challenge in sea bream (Seiliez et al., 2003). In sea bass, partial substitution (60\%) of fish oil by vegetable oil stimulated fads2 expression in liver (GonzálesRovira et al., 2009) but did not regulate desaturation activities in hepatocytes. This lack of stimulation of FADS2 activity in sea bass is the first step causing a critical modification of HUFA flesh profile, with decreased EPA and DHA content and, increased LNA and LA levels, compromising in consequence their nutritional value for human consumers (Mourente et al., 2005).

Taken together, these results seem to indicate that the poor ability of marine fish species to synthesize EPA and DHA from vegetable oil precursors could be due, at least partly, to a misregulation of FADS2 activity. However, many differences between the studies (Mourente et al. 2002, 2005; Zheng et al., 2004), including in particular the partial substitution of fish oil in previous sea bass experiments make direct comparison difficult with other species. Moreover, there is still scarce information available in marine fish species and particularly in sea bass concerning the implication of factors such as Sterol regulatory element binding proteins-1 (SREBP-1) and peroxisome proliferator activated receptor- $\alpha$ (PPAR $\alpha$ ) that are likely to be important in controlling the regulation of FADS2 activities in mammals (Nakamura and Nara, 2003). SREBP-1 gene encodes by alternative splicing two messengers, SREBP- 
1a and SREBP-1c which activate transcription of genes involved in fatty acid synthesis including fads2 (Brown and Goldstein, 1997; Eberle et al., 2004). PPAR $\alpha$ has been shown in mammals to induce both genes involved in fatty acid oxidation and synthesis including fads2 which exhibits PPAR responsive element (PPRE) in its promoter.

This prompted us to further investigate the nutritional regulation of FADS2 expression and activity in European sea bass fed 100\% vegetable diet or fish diet during 9 months. To this end, we 1) compared the rates of desaturation of $\left[1-{ }^{14} \mathrm{C}\right] 18: 3 n-3$ into $\left[1-{ }^{14} \mathrm{C}\right] 18: 4 \mathrm{n}-3$ from microsomal preparations obtained from the liver and anterior intestine of the two dietary groups by means of high-performance liquid chromatography (HPLC). 2) investigated the effect of fish meal and fish oil substitution on the relative quantity of FADS2 as well as SREBP-1 and PPAR $\alpha$ transcripts by quantitative PCR in both tissues. And 3) analysed the impact of substitution through the analysis of HUFA content in flesh.

\section{Materials and methods}

\subsection{Diets and fish}

Two iso-energetic and iso-nitrogenous experimental diets were formulated with a constant lipid content (Table 1). The fish diet (FD) was composed by fish meal, gluten and fish oil whereas the vegetable diet (VD) devoided fish origin ingredients and was composed by vegetable meals and vegetable oil (linseed). Proximate and fatty acid compositions are given in Table 1. Sea bass obtained from a Mediterranean stock held at the Station of Palavas-lesFlots (Ifremer institute, France) were stocked randomly into four tanks of 5000L capacity supplied with recirculated seawater (38ppt) at constant temperature of $21^{\circ} \mathrm{C}$ and were subjected to a photoperiod of 12 light :12 dark and fed with a commercial diet (Gouessant Neogreower) before the trial. After the acclimatation period of 2 weeks, 200 fish per tank (weight: $200 \mathrm{~g} \pm 50 \mathrm{~g}$ ) were hand fed to satiation (1 meal/day) for a period of 9 months. During the experiment, no significant difference of mortality was observed between the two dietary treatments. After 9 months, thirty fish per dietary treatment were sampled in the same day.

\subsection{Lipid extraction and fatty acid analysis}

$1 \mathrm{~g}$ of white muscle was dissected from thirty fish per dietary treatment and were immediately frozen in liquid nitrogen. Total lipids were extracted by the Accelerated Solvent Extraction 200 (ASE, Dionex) with dichloromethane/methanol (2:1) containing 0,01\% butylated hydroxutoluene $(\mathrm{BHT})$ as antioxidant. Lipids were extracted at 100 bars, $100^{\circ} \mathrm{C}, 5 \mathrm{~min}$ precalling and 2 min static phases, and $60 \%$ of flush during $60 \mathrm{sec}$ (3cycles). Total lipids were prepared according to the method of Folch et al. (1957). The weight of lipid was determined gravimetrically after evaporation of solvent. Fatty acid methyl esters (FAME) were prepared from total lipids by acid-catalyzed trans-esterification.

FAME were quantified by gas-liquid chromatography (Clarus 500 , Perkin Elmer) with column BPX70 of $30 \mathrm{~m}$ length and $0.22 \mathrm{~mm}$ I.D. Hydrogen was used as carrier gas and temperature programming was from $50^{\circ} \mathrm{C}$ to $180^{\circ} \mathrm{C}$ at $20^{\circ} \mathrm{C} / \mathrm{min}$ and then to $220^{\circ} \mathrm{C}$ at $3^{\circ} \mathrm{C} / \mathrm{min}$. Individual methyl esters were identified by comparison to known standards. The fatty acid analysis was performed on one sample per fish.

\subsection{Fatty acid desaturation in liver and intestine microsomes}

For microsomal preparation, $5 \mathrm{~g}$ of frozen liver and intestine of each fish (thirty fish of each dietary treatment) were homogenized to $10 \%(\mathrm{w} / \mathrm{v})$ in a solution $\mathrm{pH} 7,4$ containing $0,25 \mathrm{M}$ sucrose, $50 \mathrm{mM} \mathrm{Na} \mathrm{PO}_{4}, 2 \mathrm{H}_{2} \mathrm{O}, 50 \mathrm{mM} \mathrm{Na} 2 \mathrm{HPO} 4,7 \mathrm{H}_{2} \mathrm{O}$, with $10 \mathrm{mM}$ EDTA and 0,1mM 
dithiotheritol (DTT). The mix was centrifuged at $10000 \mathrm{~g}$ for $30 \mathrm{~min}$ at $4^{\circ} \mathrm{C}$ (Beckman, Optima L-70K Ultracentrifuge). The supernatant was collected in a new tube and centrifuged at $105000 \mathrm{~g}$ for $60 \mathrm{~min}$ at $4^{\circ} \mathrm{C}$. The pellet was washed in a solution $\mathrm{pH} 7,4$ containing $100 \mathrm{mM}$ $\mathrm{Na}_{4} \mathrm{P}_{2} \mathrm{O}_{7}, 10 \mathrm{mM}$ EDTA and 0,1 mM DTT. Homogenate was centrifuged at $105000 \mathrm{~g}$ for 60 min at $4{ }^{\circ} \mathrm{C}$ and pellet was homogenised in a solution buffer of $20 \%$ glycerol $(\mathrm{v} / \mathrm{v}) \mathrm{pH} 7,4$ containing $80 \mathrm{mM} \mathrm{K}_{2} \mathrm{HPO}_{4}, 3 \mathrm{H}_{2} \mathrm{O}, 20 \mathrm{mM} \mathrm{KH}_{2} \mathrm{PO}_{4}, 1 \mathrm{mM}$ DTT and 1mM EDTA. Microsomal protein content was determined using Bio-Rad protein assay (Bio-Rad, Hercules, CA, USA) based on the Bradford (1976) dye-binding procedure using bovine serum albumin as standard.

Microsomal preparation $(200 \mu \mathrm{g})$ was incubated with C18:3n-3 substrate (isotopic dilution for a final concentration of $80 \mu \mathrm{M}$ ) in a solution of phosphate buffer with $6 \mathrm{mM} \mathrm{MgCl}, 0.54 \mathrm{mM}$ coenzyme A, $72 \mathrm{mM}$ ATP and $0.8 \mathrm{mM} \mathrm{NADH}$ in a total volume of $1 \mathrm{ml}$ during $20 \mathrm{~min}$. Saponification was performed by addition of $1 \mathrm{ml} \mathrm{KOH}$ in ethanol $(12 \%$, W/V) for $30 \mathrm{~min}$ at $70^{\circ} \mathrm{C}$ and acidified back with $1 \mathrm{ml} \mathrm{3M} \mathrm{HCl}$. The C18:3n-3 substrate and the specific product of desaturation were extracted by diethylether and separated by RP-HPLC using a 5- $\mu \mathrm{m}$ Ultrasphere C18 column $250 \times 4.6 \mathrm{~mm}$ (Beckman, France) with a gradient of mobile phase. The HPLC chromatography apparatus was equipped with a Flo-One Beta radiometric detector (Packard, Meriden, CT). Metabolic rates were calculated from the percenttransformed areas of metabolites and expressed in pmol $\mathrm{min}^{-1} \mathrm{mg}^{-1}$ of protein.

\subsection{Western-blot analyses}

Three pools of 10 fish were investigated by western-blot in both dietary treatments. Total protein contained in liver and intestine microsomal preparations was quantified using a DC protein assay (Bio-Rad, Hercules, CA, USA) and adjusted to a final concentration of 1 mg.ml ${ }^{-1}$ in a solution buffer of $20 \%$ glycerol $(\mathrm{v} / \mathrm{v}) \mathrm{pH} 7,4$ containing $80 \mathrm{mM} \mathrm{K}_{2} \mathrm{HPO}_{4}, 3 \mathrm{H}_{2} \mathrm{O}, 20$ $\mathrm{mM} \mathrm{KH} \mathrm{PO}_{4}, 1 \mathrm{mM}$ DTT and $1 \mathrm{mM}$ EDTA. Thirty micrograms of each microsomal protein extract were separated in a 10\% SDS-polyacrylamide gel electrophoresis (SDS-PAGE) and transferred onto polyvinylidene fluoride PVDF membrane for immunodetection on westernblot as described in Corporeau \& Auffret (2003). For immunodetection, we used a mixture of two heterologous polyclonal sera (S1 and S2) directed against the C-terminal and N-terminal region of the rat FADS2 protein, respectively. These sera were obtained from the laboratory of INRA-ENSA (Rennes, France) by immunizing rabbits with two peptide corresponding to the rat FADS2 (GenBank accession no. AB021980, D'Andrea et al., 2002). The membrane was probed with a mixture of S1 and S2 sera, each diluted at 1:2000 in PBS buffer containing $3 \%$ BSA and $0.1 \%$ tween-20. Blots were then incubated with secondary goat antirabbit antibody diluted at 1:5000, and bands were revealed using an Immun-star AP detection kit (Bio-Rad Hercules, CA, USA). The relative intensity of the band corresponding to FADS2 protein was quantified using MULTI-ANALYST software (Bio-Rad,Hercules, CA, USA) after removal of the background. The obtained value was expressed in $\mathrm{OD} / \mathrm{mm}^{2}$, and represents the spot intensity expressed as mean count per pixel, multiplied by the spot surface. Results were standardized as a ratio of protein stained with Comassie brilliant blue (LC: loading control).

\subsection{RNA extraction and semi-quantitative real-time PCR analysis}

Total mRNA of liver and intestine was extracted using Trizol reagent (Invitrogen, USA), and quantified by measuring absorbance at $260 \mathrm{~nm}$ in a spectrophotometer (Nanadrop Labtech, France). The reverse transcription was performed using the kit QuantiTect ${ }^{\circledR}$ Reverse Transcription (QIAGEN) including a step of genomic DNA elimination. Reactions were carried out in $20 \mu \mathrm{l}$ of volume containing $1 \mu \mathrm{g}$ of total RNA, $1 \mu \mathrm{l}$ Quantiscript Reverse 
Transcriptase, $4 \mu \mathrm{l}$ Quantiscript RT buffer (5X) and $1 \mu$ l Primer Mix and sterile MilliQ water. At the end of the RT reactions, all cDNA were kept at $-20^{\circ} \mathrm{C}$. FADS2, SREBP-1, PPAR $\alpha$ and the housekeeping Elongation Factor 1 (EF1) gene expressions were determined by real time PCR. In this study, EF1 was not regulated by dietary treatment and could be used as a reference gene. The relative mRNA levels of FADS2, PPAR $\alpha$ and SREBP-1 in each sample were normalized with EF1 expression calculated with the comparative threshold cycle (Ct) method (Whelan et al., 2003). Specific primers (Table 2) were designed from European seabass sequence of FADS2 (GenBank accession no. EU439924), SREBP-1 (GenBank accession no. FN677951), PPARa (GenBank accession no. AY590300) and EF1 (GenBank accession no. AJ866727). The PCR reaction was carried out in an i-cycler with a optical module (Bio-Rad, Hercules, CA, USA) in a final volume of $20 \mu \mathrm{l}$ containing $7.5 \mu \mathrm{l}$ of SYBR Green Supermix (Biorad, Hercules, CA, USA), $5 \mathrm{~nm}$ of each primer and $0.5 \mu \mathrm{l}$ of cDNA. The PCR program consisted in an initial DNA denaturation of $94^{\circ} \mathrm{C}$ for 90 s, followed by 45 cycles at $95^{\circ} \mathrm{C}$ for $30 \mathrm{~s}, 60^{\circ} \mathrm{C}$ for $60 \mathrm{~s}$ and 80 cycles at $95^{\circ} \mathrm{C}$ for $10 \mathrm{~s}$. A triplicate of each reaction was realized for each sample.

\subsection{Statistical analysis}

Results are presented as means \pm SD. The data were checked for normal distribution by the Pearson test, as well as for homogeneity of the variances with the Bartlett test. Effect of treatment was tested using Student's $t$-test or one-way ANOVAs. In all statistical analysis test used, $\mathrm{P}<0.05$ was considered statistically different. The statistical analysis were performed by using the Statistica biosoft 8.0.

\section{Results}

\subsection{Effect of the dietary treatments on growth performance.}

Total weight of fish was around 3-fold higher at the end of the nutritional challenge compared to the start of the experiment (Table 3). In addition, a significant difference was observed in fish final weight between dietary treatments, with values of $+17.5 \%$ for fish fed FD by comparison with fish fed VD. Mortality over the experimental period did not exceed $1 \%$ and showed no significant differences among dietary treatments.

\subsection{Effect of the diets on FA composition of flesh.}

Total fatty acid composition in flesh of fish fed FD included approximately $20 \%$ total saturates, $6.5 \% \mathrm{n}-6$ fatty acids predominantly $18: 2 \mathrm{n}-6$, and almost $28 \% \mathrm{n}-3$ fatty acids, predominantly EPA (8.6\%) and DHA (16.2\%) (Table 4). This composition is close to the initial flesh composition. On the contrary, substituting fish ingredients with vegetable ingredients resulted in a large increase of 18:2n-6 and 18:3n-3 proportions whereas 20:5n-3 (EPA), 22:6n-3 (DHA) and 20:4n-6 (Arachidonic acid) reached only the third of the values obtained with FD. Moreover, fish nourished with VD contained $0.82 \%$ of $18: 4 n-3$ and $0.18 \%$ of $20: 4 n-3$ whereas there were absent in the diet.

\subsection{Effect of the diets on FADS2 activity and protein levels in liver and intestine.}

The effect of diet on the activity and the protein content of FADS2 was determined in liver and intestine (Figures 2 - 3). There was no significant effect of the diets onto the FADS2 
activity in the microsomal fraction of liver and intestine. Desaturase $\left[1-{ }^{14} \mathrm{C}\right] 18: 4 \mathrm{n}-3$ conversion was around $170 \mathrm{pmol} / \mathrm{mn} / \mathrm{mg}$ protein in liver microsomes and around 150 $\mathrm{pmol} / \mathrm{mn} / \mathrm{mg}$ protein for intestine microsomes. To confirm the specific detection of $\left[1-{ }^{14} \mathrm{C}\right]$ 18:4n-3 product by HPLC we analysed the microsomal fraction of yeast transfected with the expression vector pYES2.1 TOPO including the seabass FADS2 CDNA (data not shown). A microsomal preparation of yeast transfected by the same expression vector without insert was used as control. This analysis showed a specific peak in the microsomal fraction transfected with the pYES2.1 TOPO vector with fads2 gene (Figure 1).

The same microsomal fractions were analysed by western blot to evaluate their FADS2 protein contents (Figure 3). In the microsomal fractions of liver and intestine, FADS2 protein concentrations were identical between FD and VD groups. These results were confirmed by normalization as a ratio of protein stained with comassie brilliant blue.

\subsection{Effect of the diets on fads2, ppar $\alpha$ and srebp-1 gene expression in liver and}

intestine.

The effect of diet on the relative expression of fads2, ppar $\alpha$ and srebp-1 gene was determined in liver and intestine (Figure 4). VD induced a significant increase in fads2 expression in liver and intestine. Fads2 mRNA levels were 4-fold and 7-fold higher in the liver and intestine of VD group, respectively. In the same way, srebp-1 expression level in the liver and intestine were respectively 10-fold and 3,5-fold higher in VD group while no significant variation of ppara messenger levels were observed between the two dietary groups.

\section{Discussion}

FADS2 activity, involved in the first step of bioconversion of C18-short chain PUFA LNA and LA to n-3 long chain HUFA (EPA, DHA and arachidonic acid), is known to be under nutritional regulation in several vertebrate species (Igal et al. 1991; Nakamura et al., 2002). For instance, in salmonids fed vegetable oils rich in LNA and LA, the activity of FADS2 is stimulated when compared to those fed fish oil rich in n-3 HUFA (EPA, DHA) (Buzzi et al., 1996; Bell et al., 2001). Several works have demonstrated that this stimulation of FADS2 activity is correlated to an up regulation of fads2 gene expression and is linked to low dietary HUFA contents combined to high LNA and LA levels (Zheng et al., 2004, 2005a). Until now, this metabolic regulation induced controversial conclusions in marine fish species including the European sea bass since previous study have shown that the partial substitution of fish oil with vegetable oil did not increase desaturase activities in the liver of this species (Mourente et al., 2005). However, the fact that sea bass exhibits the particularity to store high lipid levels including HUFA in their liver in comparison with other freshwater species (Mourente and Bell, 2006) could influence the hepatic HUFA contents and the expected nutritional regulation when partial substitution is performed.

In the present study, sea bass were fed $100 \%$ vegetable diet totally devoid in HUFA during 9 months. Contrary to previous results obtained with partial fish oil substitution (Mourente et al., 2002, 2005), this total substitution compromised growth performance, revealing a nutritional deficiency. This is consistent with Skalli and Robin (2004) results, determining the n-3 HUFA requirement around $0.7 \%$ diet dry matter (or $18 \%$ of total dietary lipids) in sea bass.

This diminution of growth performance can be correlated to the significant decrease in $n-3$ HUFA contents observed in flesh of fish fed vegetable diet (Tocher et al., 1989; Rodriguez et 
al., 1994; Sargent et al., 1995; Ibeas et al., 1996; Oliva-Teles, 2000; Parpoura and Alexis, 2001; Skalli and Robin, 2004).

Another reason could be linked to the low arachidonic acid content of the vegetable diet compared to fish diet. Indeed, an arachidonic acid requirement has been reported for growth in different fish such as turbot (Castell et al., 1994). Finally, the supply of protein as vegetable meals could be another reason explaining the lower final weight of the VD sea bass, since it has been previously shown that fish meal replacement by vegetable protein can reduce growth in this species (Tibaldi et al. 2006). However, in this experiment, a blend of vegetable meals was used and lysine was added for optimising the protein composition of vegetable diet and meeting the amino acid requirement of sea bass.

The analysis of fatty acid profile in muscle in these fish confirmed that the fatty acid composition of the flesh is directly influenced by the lipid composition of the diet as previously described by Mourente et al. (2006), even if some specific fatty acids are selectively retained or utilised (Tocher et al., 2003; Mourente et Bell, 2006). The main representative fatty acids in vegetable diet are LNA and LA and they are found to accumulate in muscle revealing the reduced capacity for desaturation and elongation in sea bass. However, intermediates in HUFA biosynthesis pathway such as, C18:4n-3, C20:4n-3, C20:5n-3, C22:6n-3, C20:2n-6, C20:4n-6 were found at higher values in muscle than in the diets of fish fed vegetable diets. Even if their absolute levels were low, our results suggested that some desaturation and elongation might have occurred. Indeed, this low biosynthesis of HUFA, might explain why, 9 months of total fish oil substitution by vegetable oil did not affect the survival rate of the fish even though the growth was significantly depressed.

The capacity of desaturation in fish fed vegetable diet was confirmed by FADS2 activity investigation using $\left[1-{ }^{14} \mathrm{C}\right] 18: 3 \mathrm{n}-3$ as substrate in microsomal preparations originated from liver and intestine, which are the most important tissues involved in HUFA metabolism pathway in fish (Bell et al., 2003). The investigation was performed on microsomal preparation since FADS2 in sea bass was preferentially located at this subcellular level (Gonzáles-Rovira et al., 2009). Specific activity of FADS2 desaturation was confirmed by analysis of microsomal fractions of yeast (Saccharomyces cerevisae) transfected with the FADS2 cDNA (data not shown).

In this experiment, the comparison between the two dietary groups revealed that the use of a vegetable diet totally deprived in HUFA did not up-regulate the FADS2 activity at hepatic and intestinal levels. This result is similar to those obtained in other marine fish species: Atlantic cod fed a HUFA-free diet did not exhibit an increase of total desaturation/elongation activities in liver and intestine (Tocher et al. 2006). The absence of FADS2 activity regulation for this marine specie is different to what is observed for freshwater species such as salmonids. In rainbow trout (Oncorhynchus mykiss), increased hepatic FADS2 activities were induced in fish fed a diet containing olive oil compared to fish fed a fish oil diet (Buzzi et al., 1996). In Atlantic salmon fed diets containing vegetable oils (rapeseed, palm and linseed oils), hepatic desaturations of LA and LNA were significantly greater when compared to fish fed diets containing fish oil (Fonseca-Madrigal et al., 2006; Kennedy et al., 2006). In freshwater species, the increase of FADS2 activity could be explained by a stimulation of fads2 gene expression (Zheng et al., 2004, 2005a).

Since western-blot analysis performed in microsomal fractions did not reveal any significant differences in FADS2 protein contents at hepatic or intestinal level between FD and VD groups, we were prompted to investigate the relative amounts of fads2 messengers, as well as those related to two genes (srebp-1 and PPAR $\alpha$ ) involved in fads2 gene regulation in mammals (Rodriguez et al., 2006). The qPCR results showed a significant increase of FADS2 transcript in both hepatic and intestinal tissues. The level of induction of fads2 gene expression found in this experiment (4-fold induction) is consistent with that obtained in previous studies performed on marine fish species such as sea bass fed $60 \%$ oil-replaced diet (5-fold induction, Gonzáles-Rovira et al., 2009) and sea bream fed rapeseed and 
Soybean oils (6-fold induction, Izquierdo et al., 2008). Moreover, this level of induction in sea bass is also comparable with that observed in liver and intestine of freshwater species such as Atlantic salmon (2-3 fold induction, Zheng et al., 2005a). It is well documented in mammals that key regulators of desaturase gene expression are srebp-1 gene products (SREBP-1a and SREBP-1c) that mediate transcriptional activation of fads2 genes by HUFAs (Nakamura et Nara, 2002). In the present study, fads2 gene stimulation in sea bass fed the VD was shown to be correlated with srebp-1 gene induction demonstrating for the first time in marine fish species that fads2 expression induced by SREBP-1 was not disrupted and neither responsible for the misregulation of FADS2 activity. Instead, the stimulation of fads2 gene expression was not found to be related to an induction of PPARa gene expression in VD fish group. It has been suggested in mammals that the induction of desaturases by PPARa could correspond to a compensatory response to an accelerated degradation and an increased demand for unsaturated fatty acids (Nakamura et Nara, 2002). Present data suggest that this regulation pathway did not seem to occur in sea bass fed vegetable diet in adult fish suffering from HUFA deficiency. Such PPAR regulation could be stage-specific since Vagner et al. (2008) described a significant increase of PPARa gene expression in sea bass larvae fed vegetable oil.

Several hypothesis related to a post transcriptional regulation could explain the lack of stimulation of FADS2 activity despite the up-regulation of fads2 gene expression. A study performed in rat presented evidences that a post-transcriptional regulation of FADS1 was due to an anti-sense RNA (Dreesen et al., 2006). This hypothesis is reinforced by the possible existence of a tremendous reservoir of non-coding RNA that are estimated to represent more than $90 \%$ of the transcriptional output of the human genome (Beiter et al., 2007, 2009). In addition, it has to be taken into account that the post-transcriptional regulation might be under the control of microRNA. Indeed, as demonstrated for many species, the presence of microRNA could be correlated with the protein inactivation implied in various physiological functions (Mc Daneld, 2009; Levine et al., 2007). Finally, as already described with the regulation of fads3 expression in yeast (Saccharomyces cerevisae), the mis-regulation of FADS2 activity could be a consequence of a regulation of mRNA stability (Vemula et al.,1998).

The lack of stimulation of the FADS2 activity observed in this study can have another origin. Indeed, as shown by Mitchell et al. (2003) on rat cells, a HUFA n-3 deficiency could induce a modification in membrane conformation, resulting in a modification of membranous protein activity involved in the signal transduction to the cell.

Similarly, the use of a vegetable diet totally deprived in HUFA n-3 could in sea bass modify the membrane composition, particularly at the level of the microsoms, inducing a change in the FADS2 activity.

The causal mechanism responsible for increased HUFA biosynthesis activity during limited dietary HUFA intake is unclear and seems to be species dependent. In our study, we showed that the use of a vegetable diet totally deprived of EPA and DHA induces a stimulation of the fads2 gene expression in the liver and in the intestine of European sea bass without any increase of its enzymatic activity. The inactivation of this metabolic pathway step could explain that European sea bass has very low capacity to bioconvert PUFA into HUFA when vegetable diet was used.

\section{Acknowledgments}

We thank H. Le Delliou and C. Grassi for their technical assistance. We wish to acknowledge Dr P. Legrand from the INRA-ENSA of Rennes (France) to have provided the antibodies, Dr S. Kaushik for diet formulation and Dr J. Robin for fatty acid analysis. 
Table 1: Formulation ( $100 \mathrm{~g}^{-1}$ ), chemical composition (\%DM) and fatty acid composition (\%FAME) in two experimental diets (FD and VD).

\begin{tabular}{|c|c|c|}
\hline Diets & FD & VD \\
\hline \multicolumn{3}{|l|}{ Ingredients } \\
\hline Fish meal & 38,0 & 0,0 \\
\hline Corn gluten & 18,0 & 20,0 \\
\hline Soybean meal & 0,0 & 18,2 \\
\hline Wheat gluten & 7,2 & 20,0 \\
\hline Wheat meal & 25,3 & 7,2 \\
\hline Lupin meal & 0,0 & 14,0 \\
\hline Soy lecithin & 0,0 & 1,0 \\
\hline Fish oil & 8,5 & 0,0 \\
\hline Linseed oil & 0,0 & 9,4 \\
\hline L-lysine & 0,0 & 2,7 \\
\hline calcium hydrogen phosphate & 0,0 & 3,0 \\
\hline Liant & 1,0 & 1,0 \\
\hline Attract mix & 0,0 & 1,5 \\
\hline Vitamins premix & 1,0 & 1,0 \\
\hline Minerals premix & 1,0 & 1,0 \\
\hline \multicolumn{3}{|l|}{ Chemical composition } \\
\hline Dry matter (\%) & 94,5 & 90,3 \\
\hline Ash & 6,3 & 7,9 \\
\hline Crude protein (\%DM) & 49,8 & 50,3 \\
\hline \multicolumn{3}{|l|}{ Fatty acids composition } \\
\hline$\Sigma$ saturates & 27,7 & 11,8 \\
\hline$\Sigma$ monoenes & 36,3 & 23,9 \\
\hline $18: 2 n-6$ & 8,9 & 23,6 \\
\hline $20: 2 n-6$ & 0,3 & 0,1 \\
\hline $18: 3 n-6$ & 0,2 & 0,1 \\
\hline $20: 4 n-6$ & 0,7 & 0,0 \\
\hline$\Sigma$ n-6 PUFA & 10,3 & 23,9 \\
\hline 18:3n-3 & 1,3 & 40,9 \\
\hline $18: 4 n-3$ & 1,8 & 0,0 \\
\hline $20: 3 n-3$ & 0,1 & 0,1 \\
\hline $20: 4 n-3$ & 0,9 & 0,0 \\
\hline $20: 5 n-3$ & 9,5 & 0,1 \\
\hline $22: 5 n-3$ & 1,6 & 0,0 \\
\hline $22: 6 n-3$ & 10,5 & 0,1 \\
\hline$\Sigma$ n-3 PUFA & 25,7 & 41,1 \\
\hline total lipid (\%) & 13,8 & 13,1 \\
\hline
\end{tabular}


Table 2: Primers used for each gene expression analysis by q-PCR

\begin{tabular}{lll}
\hline & Forward primers (5'-3') & Reverse primers (3'-5') \\
\hline FADS2 & CCTTCACTGCTTTCATCCCAA & CCCAGGTGGAGGCAGAAGAA \\
SREBP-1 & CTGGAGCCAAAACAGAGGAG & GACAGGAAGGAGGGAGGAAG \\
PPAR & ACCTCAGCATCAGGTGACT & AACTTCGGCTCCATCATGTC \\
Elongation Factor $\alpha($ EF1 $\alpha)$ & GCTTCGAGGAAATCACCAG & CAACCTTCCATCCCTTGAAC \\
\hline
\end{tabular}

Table 3: Growth and survival for seabass fed fish diet and vegetable diet for 9 months. Data are presented as means \pm SD $(n=60)$. Mean values in similar row with different superscript letters are significantly different (Student's $t$-test, $\quad \mathrm{P}<0.05$ )

\begin{tabular}{|c|c|c|}
\hline & Fish diet & Vegetable diet \\
\hline Initial weight (g) & $193 \pm 56$ & $190 \pm 53$ \\
\hline Final weight (g) & $623 \pm 169^{b}$ & $530 \pm 142^{a}$ \\
\hline $\mathrm{DGC}^{1\left(10^{\wedge}-4\right)}$ & $103.5 \pm 5.7$ & $91 \pm 3.3$ \\
\hline Survival (\%) & $99.5 \%$ & $100 \%$ \\
\hline
\end{tabular}

Table 4: Fatty acid composition (\% of total fatty acids) in muscle from fish fed vegetable diet (VD) and fish diet (FD) at the beginning and at the end of the trial. Mean values in similar row with different superscript letters are significantly different (One-way ANOVA, $P<0.05$ )

\begin{tabular}{|c|c|c|c|}
\hline Diets & FD & VD & initial \\
\hline \multicolumn{4}{|c|}{ Fatty acids composition } \\
\hline$\sum$ saturates & $20 \pm 3,1^{\mathrm{a}}$ & $28,4 \pm 2,2^{c}$ & $26,1 \pm 0,4^{b}$ \\
\hline$\Sigma$ monoenes & $20,2 \pm 1,5^{a}$ & $20,8 \pm 2,7^{\mathrm{a}}$ & $24,4 \pm 0,6^{b}$ \\
\hline $18: 2 n-6$ & $4,7 \pm 0,5^{a}$ & $16,7 \pm 0,9^{c}$ & $6,8 \pm 0,7^{b}$ \\
\hline $20: 2 n-6$ & $0,3 \pm 0,1^{a}$ & $0,9 \pm 0,1^{c}$ & $0,5 \pm 0,1^{b}$ \\
\hline 18:3n-6 & $0,1 \pm 0,1^{a}$ & $0,1 \pm 0,0^{a}$ & $0,1 \pm 0,1^{a}$ \\
\hline $20: 4 n-6$ & $1,4 \pm 0,3^{b}$ & $0,5 \pm 0,1^{a}$ & $1,3 \pm 0,1^{b}$ \\
\hline$\Sigma \mathrm{n}-6$ HUFA & $6,5 \pm 0,4^{a}$ & $18,2 \pm 0,7^{c}$ & $8,8 \pm 0,3^{b}$ \\
\hline $18: 3 n-3$ & $0,7 \pm 0,1^{a}$ & $17,4 \pm 1,0^{c}$ & $1,2 \pm 0,5^{b}$ \\
\hline $18: 4 n-3$ & $0,6 \pm 0,2^{a}$ & $0,8 \pm 0,1^{b}$ & $1,2 \pm 0,2^{c}$ \\
\hline $20: 3 n-3$ & $0,1 \pm 0,0^{a}$ & $0,1 \pm 0,1^{a}$ & $0,1 \pm 0,1^{a}$ \\
\hline $20: 4 n-3$ & $0,4 \pm 0,1^{b}$ & $0,2 \pm 0,0^{a}$ & $0,6 \pm 0,1^{c}$ \\
\hline $20: 5 n-3$ & $8,7 \pm 1,0^{b}$ & $2,7 \pm 0,5^{a}$ & $11,9 \pm 0,5^{c}$ \\
\hline $22: 5 n-3$ & $1,3 \pm 0,2^{b}$ & $0,5 \pm 0,1^{a}$ & $1,7 \pm 0,1^{\mathrm{C}}$ \\
\hline $22: 6 n-3$ & $16,2 \pm 2,4^{b}$ & $5,3 \pm 1,1^{a}$ & $15,6 \pm 0,9^{b}$ \\
\hline$\Sigma$ n-3 HUFA & $28,0 \pm 1,2^{\mathrm{a}}$ & $27,1 \pm 0,9^{a}$ & $32,4 \pm 0,4^{\mathrm{C}}$ \\
\hline
\end{tabular}




\section{Figures}

Figure 1: Representative HPLC profiles generated from $\left[1-{ }^{14} \mathrm{C}\right] 18: 3 n-3$ by microsomes of liver of sea bass fed with VD (B). Profile (A) is the negative control of the reaction. Arrow indicates the specific product of $\left[1-{ }^{14} \mathrm{C}\right] 18: 3 n-3$ desaturation.

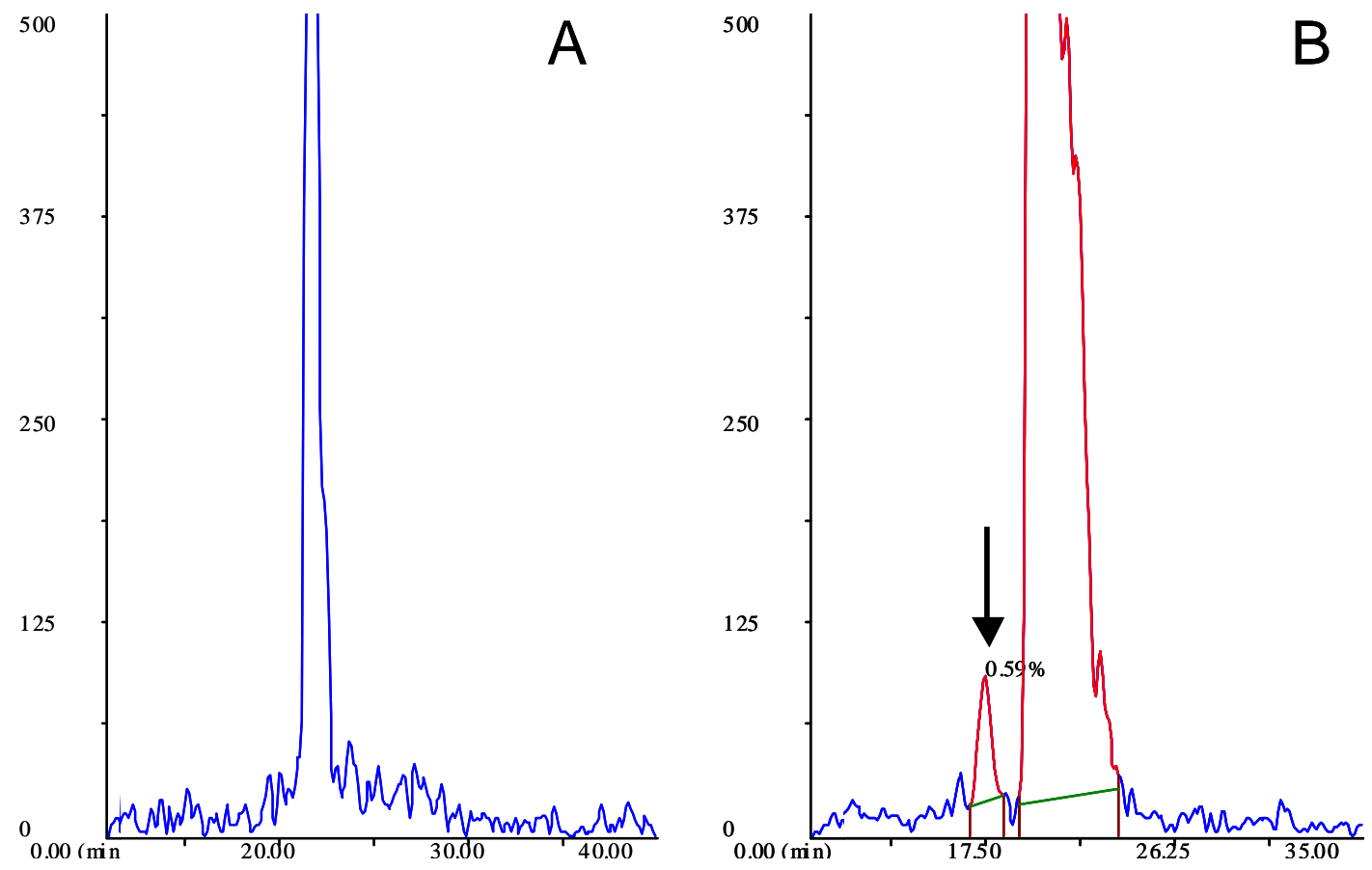


Figure 2: FADS2 n-3 microsomal desaturase activities in liver and intestine. Results are means \pm S.D. $(n=3)$ and represent the conversion $\left(\mathrm{pmol} \mathrm{mn}^{-1} \mathrm{mg}\right.$ protein $\left.{ }^{-1}\right)$ of $\left[1-{ }^{14} \mathrm{C}\right] 18: 3 n-3$. Significant differences between means are indicated by different letters (Student's $t$-test, $\mathrm{P}<0.05)$

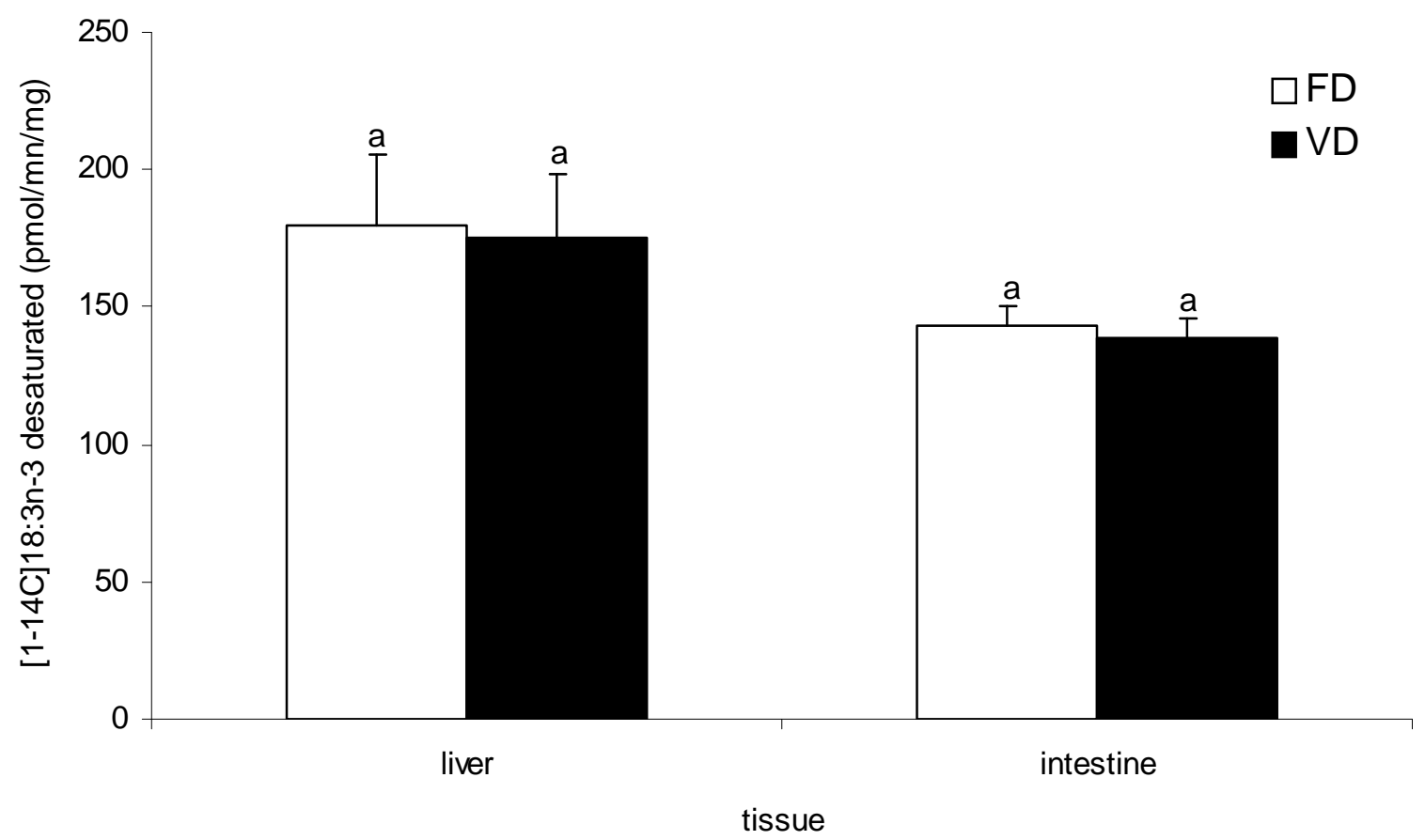


Figure 3: (A) Detection of European sea bass FADS2 protein in liver and intestine for both dietary treatments. The blot was immunoprobed with anti-rat FADS2 sera S1 and S2, both at 1:2000 dilution. Results were standardized as a ratio of protein stained with Comassie brilliant blue (LC: loading control). (B) Levels of FADS2 protein in liver and intestine in response to the dietary trial. FADS2 protein in the microsomal extracts were quantified by densitometric analysis (expressed in $\mathrm{D} / \mathrm{mm}^{2}$ ). Data in the histogram are shown as mean \pm S.D. $(n=3)$. Different letters indicate significant differences (Student's $t$-test, $P<0.05$ ).

A
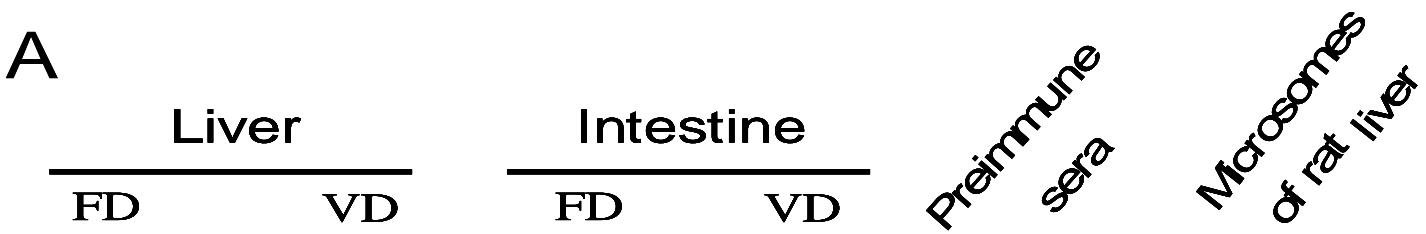

LC

\section{B}

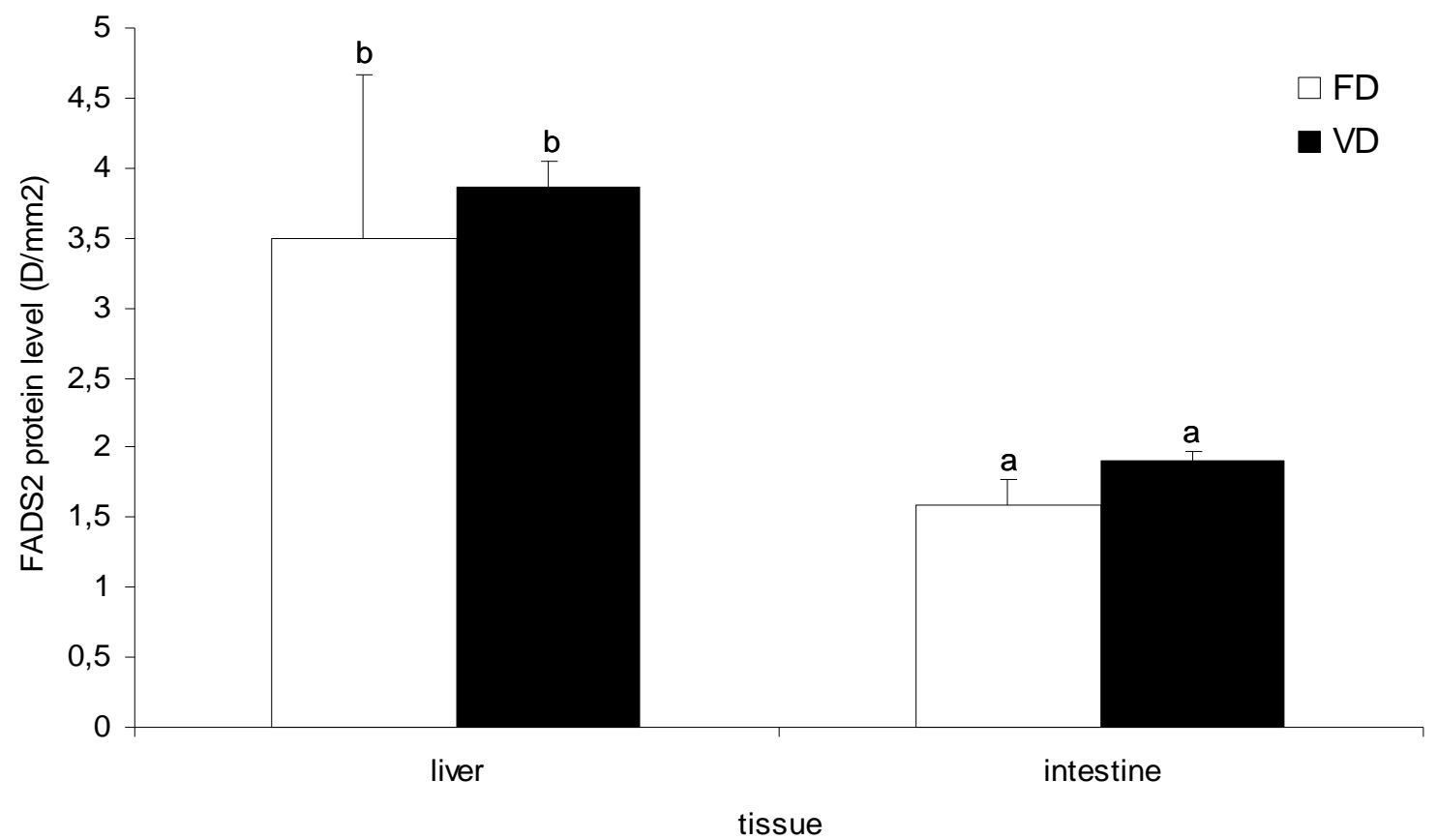


Figure 4: Relative expression of fads2, srebp-1 and ppara gene in liver and intestine from fish fed FD and VD. Relative transcript (mRNA) levels were determined by Q-PCR and normalized by Elongation Factor 1 (EF1a). Results are expressed as mean S.D. $(n=15)$. Different letters indicate significant differences (Student's $t$-test, $\mathrm{P}<0.05$ ).
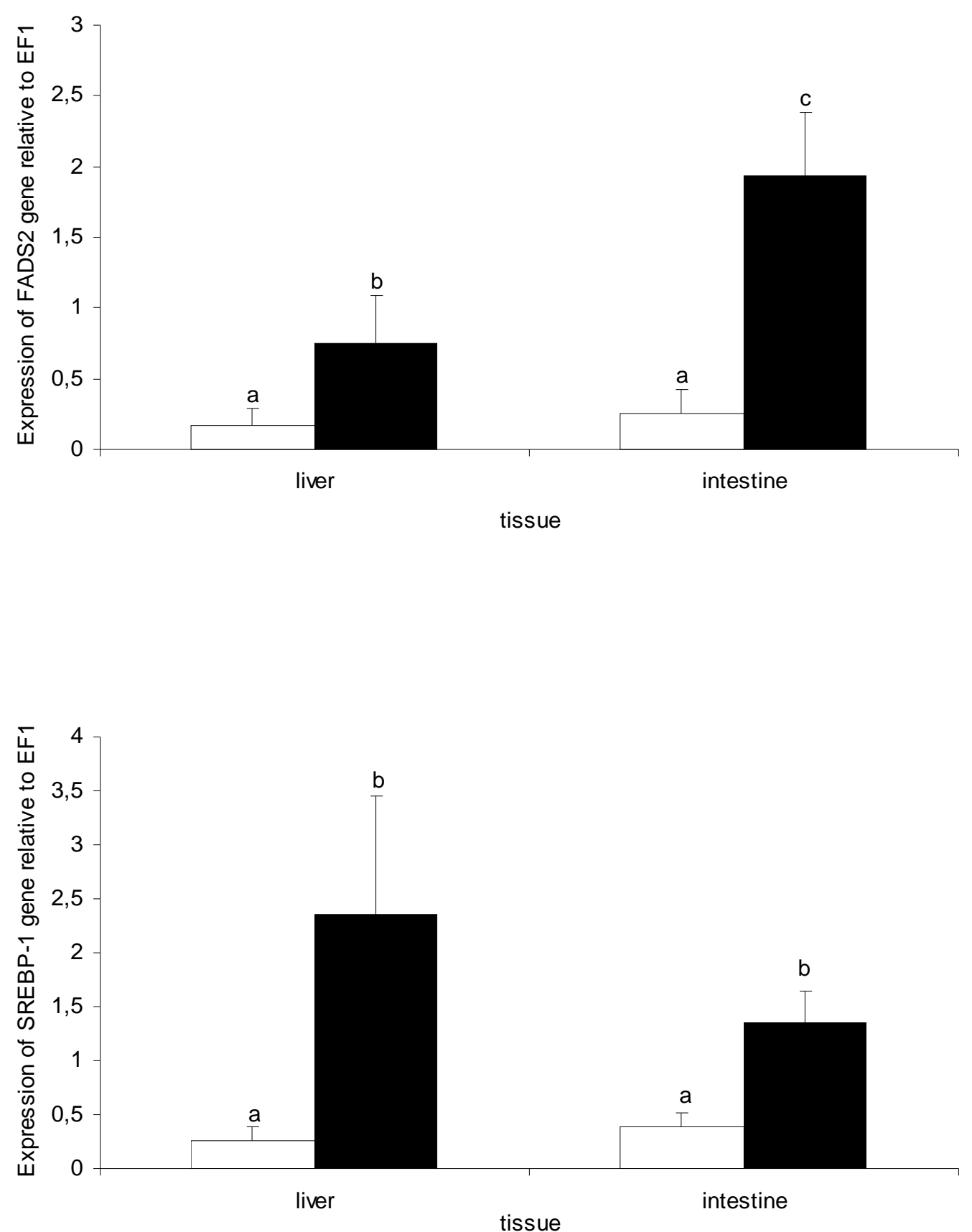


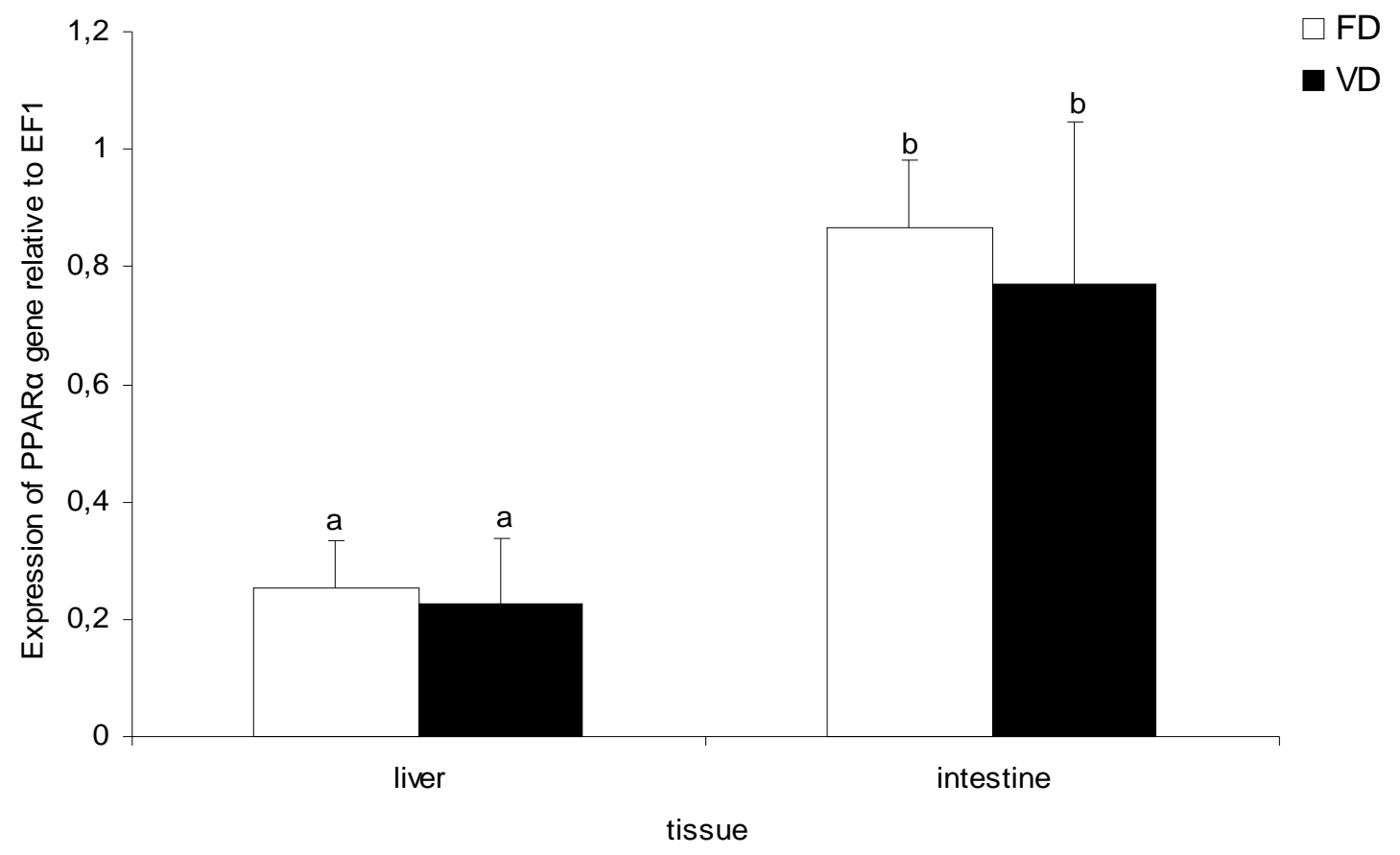




\section{References}

Beiter, T., Reich, E., Weigert, C., Niess, A.M., Simon P., 2007. Sense or antisense? False priming reverse transcription controls are required for determining sequence orientation by reverse transcription-PCR. Anal. Biochem. 369, 258-261.

Beiter, T., Reich, E., Williams, R.W., Simon, P., 2009. Review: Antisense transcription: A critical look in both directions. Cell. Mol.Life Sci. 66, 94-112.

Bell, M.V., Dick, J.R., Porter, A.E.A., 2003. Pyloric ceca are a major site of 22:6n-3 synthesis in rainbow trout (Oncorhynchus mykiss). Lipids 39, 39-44.

Bell, J.G., McEvoy, J., Tocher, D.R., McGhee, F., Campbell, P.J., Sargent, J.R. 2001. Replacement of fish oil with rapessed oil in diets of Atlantic salmon (Salmo salar) affects tissue lipid compositions and hepatocyte fatty acid metabolism. J. Nutr. 131, 1535-1543.

Bradford, M.M., 1976. A rapid and sensitive method for the quantification of microgram quantities of protein utilizing the principle of protein-dye binding. Analytical Biochem. 72, 248-254.

Brown, M.S., Goldstein, J.L., 1997. The SREBP pathway: Regulation of cholesterol metabolism by proteolysis of a membrane-bound transcription factor. Cell 89, 331-340.

Burr, G.O., 1981. The essential fatty acids fiftyyears ago. Prog. Lipid Res.20, xxvii-xxix.

Buzzi, M., Henderson, R.J., Sargent, J.R., 1996. The desaturation and elongation of linolenic acid and eicosapentaenoic acid by hepatocytes and liver microsomes from rainbow trout (Oncorhynchus mykiss) diets containing fish oil or olive oil. Biochimica et Biophysica ActaLipids and Lipid Metabolism 1299, 235-244.

Castell, J.D., Bell, J.G., Tocher, D.R., 1994. Effects of purified diets containing different combinations of arachidonic and docosahexaenoic acid on survival, growth and fatty-acid composition of juvenile turbot (Scophthalmus-maximus). Aquaculture 128, 315-333.

Cho, H.P., Nakamura M.T., Clarke S.D., 1999a. Cloning, expression, and nutritional regulation of the mammalian Delta-6 desaturase. J Biol Chem 274, 471-477.

Cho, H.P., Nakamura, M.T., Clarke, S.D., 1999b. Cloning, expression, and fatty acid regulation of the human delta-5 desaturase. J Biol Chem.274, 37335-37339.

Corporeau, C., Auffret, M., 2003. In situ hybridisation for flow cytometry: a molecular method for monitoring stress-gene expression in hemolymph cells of oysters. Aquatic toxicology 64 (4), 427-435

D'andrea, S., Guillou, H., Jan, S., Catheline, D., Thibault, J.N., Bouriel, M., Rioux, V., Legrand, P., 2002. The same rat $\Delta 6$-desaturase not only acts on 18- but also on 24-carbon fatty acids in very-long-chain polyunsaturated fatty acid biosynthesis. Biochem. J. 364, 4955.

Dreesen, T.D., Adamson, A.W., Tekle, M., Tang, C., Cho, H.P., Clarke, S.D., Gettys, T.W., 2006. A newly discovered member of the fatty acid desaturase gene family: A non-coding, antisense RNA gene to $\Delta 5$-desaturase. Prostaglandins, Leukotrienes and Essential Fatty Acids 75, 97-106. 
Eberle, D., Hegarty, B., Bossard, P., Ferre, P., Foufelle, F., 2004. SREBP transcription factors: master regulators of lipid homeostasis. Biochimie 86, 839-848.

Folch, J., Lees, M., Sloane-Stanley, G.H., 1957. A simple method for the isolation and purification of total lipids from animal tissues. J. Biol. Chem. 226, 497-509.

Fonseca-Madrigal, J., Bell, J.G., Tocher, D.R., 2006. Nutritional and environmental regulation of the synthesis of highly unsaturated fatty acids and of fatty-acid oxidation in Atlantic salmon (Salmo salar L.) enterocytes and hepatocytes. Fish Physiol. And Biochem. 32, 317-328.

Ghioni, C., Tocher, D.R., Bell, M.V., Dick, J.R., Sargent J.R., 1999. Low C18 to C20 fatty acid elongases activity and limited conversion of stearidonic acid, C18:4n-3, eicosapentaenoic acid, 20:5n-3, in a cell line from the turbot Scophthalmus maximus. Biochim. Biophys. Acta 1437, 170-181.

Gonzáles-Rovira, A., Mourente, G., Zheng, X., Tocher, D.R., Pendón, C., 2009 Molecular and functional characterization and expression analysis of a $\Delta 6$ fatty acyl desaturase cDNA of European Sea Bass (Dicentrarchus labrax L.) Aquaculture 298, 90-100.

Ibeas, C., Cejas, J., Jerez, S., Lorenzo, A., 1996. Influence of dietary n-3 highly unsaturated fatty acids levels on juvenile gilthead seabream (Sparus aurata) growth and tissue fatty acid composition. Aquaculture 142, 221-235.

Igal, R., Mandon, E., Gomez, D., 1991. Abnormal metabolism of polyunsaturated fatty acids un adrenal gland of diabetic rats. Mol. Cell. Endocrinol. 77, 217-227.

Innis, SM., 2003. Perinatal biochemistry and physiology of long-chain polyunsaturated fatty acids. J Pediatr 143, S1-8.

Kennedy, S.R., Leava, M.J., Campbell, P.J., Zheng, X., Dick, J.R., Tocher, D.R., 2006. Influence of dietary oil content and conjugated linoleic acid (CLA) on lipid metabolism enzyme activities and gene expression in tissues of Atlantic salmon (Salmo salar L.). Lipids 41, 423-436.

Levine, E., Jacob, E.B., Levine, H., 2007. Target-specific and global effectors in gene regulation by microRNA. Biophy. J. 93, 52-54.

Marquardt, A., Stohr, H., White, K., Weber, B.H., 2000. CDNA cloning, genomic structure and chromosomal localization of three members of the human fatty acid desaturase family. Genomics. 66, 175-183.

McDaneld, T.G., 2009. MicroRNA: Mechanism of gene regulation and application to livestock. Journal of Ani. Sc. 87, 21-28.

Mitchell, D.C., Niu, S., Litman B.J., 2003. Enhancement of G protein-coupled signalling by DHA phospholipids. Lipids 38, 437-443.

Mourente, G., Dick, J.R., 2002. Influence of partial substitution of dietary fish oil by vegetable oils on the metabolism of [1-C-14]18:3n-3 in isolated hepatocytes of European sea bass (Dicentrarchus labrax). Fish Physio. And Biochem. 26, 297-308.

Mourente, G., Dick, J.R., Bell, J.G., Tocher, D.R., 2005. Effect of partial substitution of dietary fish oil by vegetable oils on desaturation and beta-oxidation of [1-C-14]18:3n-3 (LNA) 
and [1-C-14]20:5n-3 (EPA) in hepatocytes and enterocytes of European sea bass (Dicentrarchus labrax L.). Aquaculture 248, 173-186.

Mourente, G., Bell, J.G., 2006. Partial replacement of dietary fish oil with blends of vegetable oils (rapeseed, linseed and palm oils) in diets for European sea bass (Dicentrarchus labrax L.) over a long term growth study: Effects on muscle and liver fatty acid composition and effectiveness of a fish oil finishing diet. Comp. Biochem. Physiol. 145, 389-399.

Nakamura, M.T., Nara, T.Y., 2002. Gene regulation of mammalian desaturases. Biochem. Soc. Trans. 30, 1076-1079.

Nakamura, M.T., Nara, T.Y., 2003. Essential fatty acid synthesis and its regulation in mammals. Prostaglandins Leukotrienes and essential fatty acids 68, 145-150.

Nakamura, MT, Nara, TY., 2004. Structure, function, and dietary regulation of delta 6, delta 5, and delta 9 desaturases. Annu Rev Nutr 24, 345-376.

Oliva-Teles, A., 2000. Recent advances in European sea bass and gilthead seabream nutrition. Aquaculture international 8, 477-492.

Owen, J. M., Adron, J.A., Middleton, C., Cowey, C.B., 1975. Elongation and desaturation of dietary fatty acids in turbot (Scophthalmus maximus) and rainbow trout (Salmo gairdneri). Lipids 10, 528-531.

Parpoura, A.C.R., Alexis, M.N., 2001. Effects of different dietary oils in sea bass (Dicentrarchus labrax) nutrition. Aquaculture international 9, 463-476.

Pike, I., 2005. Eco-efficiency in aquaculture: global catch of wild fish used in aquaculture. Int. Aquafeed 8, 38-40.

Rodriguez, C., Perez, J.A., Lorenzo, A., Izquierdo, M.S., Cejas, J.R., 1994. n-3 HUFA requierment of larval gilthead seabream sparus-aurata when using high-levels of eicosapentaenoic acid. Comp. Bioch. and Phys. A-Physiology 107, 693-698.

Rodriguez-Cruz, M., Tovar, A.R., Palacios-Gonzales, B., del Prado, M., Torres, N., 2006. Synthesis of long-chain polyunsaturated fatty acids in lactating mammary gland: role of $\Delta 5$ and $\Delta 6$ desaturases, SREBP-1, PPARa, and PGC-1. J. of Lipid Research 47, 553-560.

Santigosa, E., Geay, F., Tonon, T., Corcos, L. ,Cahu, C., Zambonino-Infante, J., Mazurais, D., 2010. Cloning, tissue expression analysis and functional characterisation of two $\Delta 6$ desaturase variants of sea bass (Dicentrarchus labrax, L.). In press in Marine Biotechnology.

Sargent, J.R., Bell, J.G., Bell, M.V., Henderson, R.J., Tocher, D.R., 1995. Requirement criteria for essential fatty acids. Journal of applied ichthyology-zeitschrift fur angewandte ichthyologie 11, 183-198.

Skalli, A., Robin, J.H., 2004. Requirement of n-3 long chain polyunsaturated fatty acids for European sea bass (Dicentrarchus labrax) juveniles: growth and fatty acid composition. Aquaculture 240, 399-415.

Seiliez, I., Panserat, S., Corraze, G., Kaushik, S., Bergot, P., 2003. Cloning and nutritional regulation of a $\Delta 6$-desaturase -like enzyme in the marine teleost gilthead seabream (Sparus aurata). Comp. Biochem. Physiol. 135, 449-460. 
Simopoulos, A.P., 2000. Human requierments for $n-3$ polyunsaturated fatty acids. Poult.Sci. 79, 961-970.

Skalli, A., Robin, J.H., 2004. Requirement of n-3 long chain polyunsaturated fatty acids for European sea bass (Dicentrarchus labrax) juveniles: growth and fatty acid composition. Aquaculture 240, 399-415.

Sprecher, H., Luthria, D.L., Mohammed, B.S., Baykousheva, S.P., 1995. Reevaluation of the pathways for the biosynthesis of polyunsaturated fatty acids. J. Lipid Res. 36, 2471-2477.

Tibaldi, E., Hakim, Y., Uni, Z., Tulli, F., De Francesco, M., Luzzana, U., Harpaz, S., 2006. Effects of the partial substitution of dietary fish meal by differently processed soybean meals on growth performance, nutrient digestibility and activity of intestinal brush border enzymes in the European sea bass (Dicentrarchus labrax). Aquaculture 261, 182-193.

Tocher, D.R., Carr, J., Sargent, J.R., 1989. Poly-unsaturated fatty-acid metabolism in fish cells-differential metabolism of $(n-3)$ and $(n-6)$ series acids by cultured-cells originating from a freshwater teleost fish and from a marine teleost fish. Comp. Biochem. And Phys. BBiochemistry and molecular biology 94, 367-374.

Tocher, D.R., Ghioni, C., 1999. Fatty acid metabolism in marine fish: low activity of $\Delta 5$ desaturation in gilthead sea bream (Sparus aurata) cells. Lipids 34, 433-440.

Tocher, D.R., Bell, J.G., MacGlaughlin, P., McGhee, F., Dick, J.R., 2001. Hepatocyte fatty acid desaturation and polyunsaturated fatty acid composition of liver in salmonids: effects of dietary vegetable oil. Comp Biochem Physiol. 137, 257-270.

Tocher, D.R., Bell, J.G., Dick, J.R., Crampton, V.O., 2003. Effects of vegetable oil diets on Atlantic salmon hepatocyte desaturase activities and liver fatty acid compositions. Lipids 38, 723-732.

Tocher, D.R., Fonseca-Madrigal, J., Dick, J.R., Ng, W.K., Bell, J.G., Campbell, P.J., 2004. Effects of temperature and diets containing palm oil on fatty acid desaturation and oxidation in hepatocytes and intestinal enterocytes of rainbow trout (Oncorhynchus mykiss). Comp. Biochem. Physiol. 137, 49-63.

Tocher, D.R, Zheng, X., Schlechtriem, C., Hastings, N., Dick, J.R., Teale, A.J., 2006. Highly unsaturated fatty acid synthesis in marine fish: cloning, functionnal characterization, and nutrionnal regulation of fatty acyl $\Delta 6$ desaturase of Atlantic cod (Gadus morhua L.). Lipids 41 , 1003-1016.

Vagner, M., Robin,J.H., Zambonino-Infante, J.L., Tocher, D.R., Person-Le Ruyet, J., 2009. Ontogenic effects of early feeding of sea bass (Dicentrarchus labrax) larvae with a range of dietary n-3 hihly unsaturaedt fatty acid levels on the functioning of polyunsaturated fatty acid desaturation pathways. British Journal of Nutrution 101, 1452-1462.

Vemula, M., Martin, C.E., 1998. Mechanisms of mRNA stability regulation in OLE1, a delta-9desaturase in Saccharomyces cerevisae. Fased Journal 12, 1282-1282.

Whelan, J.A., Russell, N.B., Whelan, M.A., 2003. A Method for Absolute Quantification of cDNA Using Real-Time PCR. J. Immun. Method. 278: 261-269.

Zheng, X., Tocher, D.R., Dickson, C.A., Bell, J.G., Teale, A.J., 2004. Effects of diets containing vegetable oil on expression of genes involved in polyunsaturated fatty acid biosynthesis in liver of Atlantic Salmon (Salmo salar). Aquaculture 236, 467-483. 
Zheng, X., Tortensen, B.E., Tocher, D.R., Dick, J.R., Henderson, R.J., Bell, J.G., 2005a. Environmental and dietary influences on highly unsaturated fatty acid biosynthesis and expression of fatty acyl desaturase and elongase genes in liver of Atlantic salmon (Salmo salar). Biochim. Biophys. Acta 1734, 13-24.

Zheng, X., Tocher, D.R., Dickson, C.A., Bell, J.G., Teale, A.J., 2005b. Highly unsaturated fatty acid synthesis in vertebrates: new insights with the cloning and characterization of a $\Delta 6$ desaturase of Atlantic Salmon. Lipids 40, 13-24. 